University of Nebraska - Lincoln

DigitalCommons@University of Nebraska - Lincoln

\title{
Yield and Agronomic Traits of Waxy Proso in the Central Great Plains
}

\author{
R. F. Heyduck \\ New Mexico State University, rheyduck@nmsu.edu \\ D. D. Baltensperger \\ University of Nebraska-Lincoln, dbaltensperger@tamu.edu \\ Lenis Alton Nelson \\ University of Nebraska-Lincoln, Inelson1@unl.edu \\ Robert A. Graybosch \\ University of Nebraska-Lincoln, bob.graybosch@ars.usda.gov
}

Follow this and additional works at: https://digitalcommons.unl.edu/usdaarsfacpub

Part of the Agricultural Science Commons

Heyduck, R. F.; Baltensperger, D. D.; Nelson, Lenis Alton; and Graybosch, Robert A., "Yield and Agronomic Traits of Waxy Proso in the Central Great Plains" (2008). Publications from USDA-ARS / UNL Faculty. 914. https://digitalcommons.unl.edu/usdaarsfacpub/914

This Article is brought to you for free and open access by the U.S. Department of Agriculture: Agricultural Research Service, Lincoln, Nebraska at DigitalCommons@University of Nebraska - Lincoln. It has been accepted for inclusion in Publications from USDA-ARS / UNL Faculty by an authorized administrator of DigitalCommons@University of Nebraska - Lincoln. 


\title{
Yield and Agronomic Traits of Waxy Proso in the Central Great Plains
}

\author{
R. F. Heyduck,^ D. D. Baltensperger, L. A. Nelson, and R. A. Graybosch
}

\section{ABSTRACT}

Proso (Panicum miliaceum L.) is a summer annual grass capable of producing seed in 60 to $90 \mathrm{~d}$. This characteristic, and its efficient use of water, makes it well suited to the short, and often hot and dry, growing season in the high plains of the central Great Plains. The introduction of novel end-use characteristics such as waxy starch can stimulate an increased market for proso. We evaluated 18 experimental $F_{5}$ waxy lines derived from a cross of 'Huntsman' and PI436626 across seven locations. Genotype $\times$ environment variation in waxy proso was mostly a matter of changes in magnitude and not crossover interaction. When crossover interaction was implicated, it was generally slight and occurred at lower environmental means-at locations with low mean response to any given variable. Waxy progeny mean yield was lower than Huntsman but significantly higher than PI436626. Except for test weight, waxy progeny mean response for most traits was similar to check cultivars. Mean yield of one experimental line did not differ significantly from Huntsman, and 14 did not differ significantly from 'Horizon', the second highest yielding cultivar. In addition, regression analysis suggests that top-yielding waxy lines responded well to high-yield environments. Seed sizes for all waxy lines were smaller than the check lines, but most were significantly larger than PI436626. Waxy lines generally headed at a similar time to Huntsman and the other nonwaxy checks, and most were significantly earlier than PI436626. Late maturity of PI436626 was the main factor limiting its culture in the High Plains region.
R.F. Heyduck, Univ. of Nebraska-Lincoln, Dep. of Agronomy and Horticulture, 321 Keim Hall, Lincoln, NE 68583; R.F. Heyduck, current address, New Mexico State Univ., Farmington Agricultural Science Center, P.O. Box 1018, Farmington, NM 87499; D.D. Baltensperger, Univ. of Nebraska-Lincoln, Panhandle Research and Extension Center, 4502 Avenue I, Scottsbluff, NE 69361; L.A. Nelson, Univ. of Nebraska-Lincoln, Dep. of Agronomy and Horticulture, 364 Keim Hall, Lincoln, NE 68583; R.A. Graybosch, USDA-ARS, 368 Keim Hall, Lincoln, NE 68583. A contribution of the University of Nebraska Agricultural Research Division, supported in part by funds provided through Anna Elliott Grant. Received 13 Feb. 2007. ^Corresponding author (rheyduck@nmsu.edu).

Abbreviations: DOY, day of year; G×E, genotype $\times$ environment.

$\mathrm{P}$ ROSO (Panicum miliaceum L.) cultivation in North America, most of which occurs in the semiarid high plains of Nebraska, Colorado, Wyoming, Kansas, and the Dakotas, has grown over the last

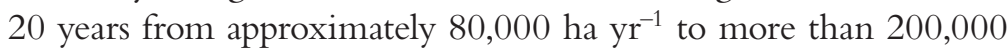
ha $\mathrm{yr}^{-1}$ in 2003 (FAO, 2008). Continued growth in the popularity of proso, as well as the increasing production of dryland maize (Zea mays L.) and sunflower (Helianthus annuus L.), brings many possibilities into an area where more intensive cropping is slowly but steadily replacing the traditional wheat (Triticum aestivum L.)-fallow system. One advantage of proso compared to maize or sunflower, however, is that it requires less water and is capable of producing a crop in 60 to $90 \mathrm{~d}$ (Baltensperger, 1996).

Proso can serve as an emergency crop that can be planted directly into frost- or hail-damaged wheat in the spring and early summer. More often, it is planted in available fallow ground that is intended for wheat planting the following fall. As a rotation crop in the wheatfallow system, this can serve to break weed, disease, and pest cycles.

Published in Crop Sci. 48:741-748 (2008).

doi: $10.2135 /$ cropsci2007.02.0081

(C) Crop Science Society of America

677 S. Segoe Rd., Madison, WI 53711 USA

All rights reserved. No part of this periodical may be reproduced or transmitted in any form or by any means, electronic or mechanical, including photocopying, recording, or any information storage and retrieval system, without permission in writing from the publisher. Permission for printing and for reprinting the material contained herein has been obtained by the publisher. 
Of crucial importance, however, is a market for this crop of rising significance. Most proso grain sold in cash trade goes to local elevators, where it is cleaned and processed before entering into the birdseed market (Baltensperger, 1996). Some proso is dehulled and is marketed for human, poultry, and animal consumption. While proso prices have historically been higher than maize or grain sorghum (Sorghum bicolor L. Moench), price levels can fluctuate dramatically. In any given year, if the birdseed and human consumption markets are saturated, the price for proso drops to feed grain levels. Price ranges from $\$ 66$ to $\$ 485$ per tonne over a five-year period are common (Bergener, 2002). A year or two following a

Table 1. Description of 30 lines entered in proso millet variety trial, 2002 and 2003. Includes 18 experimental lines, both adapted and waxy parental lines, nine regional check lines, and an additional waxy line of Chinese origin.

\begin{tabular}{|c|c|c|c|}
\hline Entry & $\begin{array}{c}\text { Starch } \\
\text { (waxy/non) }\end{array}$ & $\begin{array}{l}\text { Year of } \\
\text { release }\end{array}$ & Note \\
\hline Horizon & non & 2004 & Regional check \\
\hline Huntsman & non & 1995 & $\begin{array}{l}\text { Adapted parent of waxy test lines, } \\
\text { regional check }\end{array}$ \\
\hline Earlybird & non & 1995 & Regional check \\
\hline Sunrise & non & 1994 & Regional check \\
\hline Sunup & non & 1989 & Regional check \\
\hline Dawn & non & 1976 & Regional check \\
\hline 9213 & non & & $\begin{array}{l}\text { Regional check, } \\
\text { line under development }\end{array}$ \\
\hline $9668-17$ & non & & $\begin{array}{l}\text { Regional check, } \\
\text { line under development }\end{array}$ \\
\hline 9308 & non & & $\begin{array}{l}\text { Regional check, } \\
\text { line under development }\end{array}$ \\
\hline 9217-L & non & & $\begin{array}{l}\text { Regional check, } \\
\text { line under development }\end{array}$ \\
\hline $172-2-9$ & waxy & & Waxy test line \\
\hline $172-2-B$ & waxy & & Waxy test line \\
\hline $174-7-13$ & waxy & & Waxy test line \\
\hline $175-5$ & waxy & & Waxy test line \\
\hline $177-3-13$ & waxy & & Waxy test line \\
\hline $177-7-5$ & waxy & & Waxy test line \\
\hline $177-8$ & waxy & & Waxy test line \\
\hline $177-9-2$ & waxy & & Waxy test line \\
\hline $177-9-12$ & waxy & & Waxy test line \\
\hline $177-9-13$ & waxy & & Waxy test line \\
\hline $182-4-24$ & waxy & & Waxy test line \\
\hline $182-5-18$ & waxy & & Waxy test line \\
\hline $182-7-20$ & waxy & & Waxy test line \\
\hline 10097 & waxy & & Waxy test line \\
\hline 10107 & waxy & & Waxy test line \\
\hline 10110 & waxy & & Waxy test line \\
\hline 10127 & waxy & & Waxy test line \\
\hline 10135 & waxy & & Waxy test line \\
\hline PI436625 & waxy & & $\begin{array}{l}\text { Waxy accession of Chinese } \\
\text { origin }\end{array}$ \\
\hline PI436626 & waxy & & $\begin{array}{l}\text { Waxy parent of waxy } \\
\text { test lines in the trial }\end{array}$ \\
\hline
\end{tabular}

price crash, the price will again rise to "specialty crop" levels, and proso again becomes very popular. Due to this vast fluctuation, proso has an unstable market footing in this regional economy and in rotations and cropping systems in the region.

The introduction of novel end-use characteristics, such as "waxy" starch, can stimulate a more stable market for proso. Most common cereal starches contain 20 to 30\% amylose and 70 to $80 \%$ amylopectin (Jane et al., 1999). Waxy starches contain more than 95\% amylopectin (Demeke et al., 1997). Waxy starch will gelatinize at lower temperatures (Lineback, 1999) and results in cooked grains with a sticky surface, allowing it to be easily eaten with chopsticks. This is a preferred characteristic for Asian culinary markets.

Graybosch and Baltensperger (2008) evaluated the USDA-ARS proso collection for accessions with waxy endosperm starch and identified five accessions, four of which were from mainland China. The trait was found to be under the control of duplicate recessive alleles designated $w x-1 b$ and $w x-2 b$. Earlier evaluations of these waxy accessions had shown that they are too late to mature reliably in the High Plains; because of this, yields are very low (Heyduck et al., 2002). Waxy accessions and numerous check cultivars were crossed in a greenhouse in winter 1999 to integrate the waxy trait with agronomic traits suited for the central Great Plains. Four rounds of selection based on waxy starch characteristic, maturity, panicle architecture, seed color, and plant height produced $47 \mathrm{~F}_{4}$ experimental waxy lines, all descending from a cross of PI436626 and 'Huntsman'.

In this study, 30 lines were evaluated: 18 experimental waxy lines, both parents, an additional waxy line of Chinese origin, and a battery of nine check cultivars. Six agronomic traits were analyzed: days to heading, plant height, lodging, grain yield, test weight, and seed size. The goals were threefold: (i) to assess the genotype $\times$ environment $(\mathrm{G} \times \mathrm{E})$ interactions of the waxy lines, parental, and check proso lines; (ii) to assess the agronomic performance and stability of experimental waxy lines relative to nine cultivars that are commonly grown in the region; and (iii) To identify one or more waxy lines suitable for release as cultivars.

\section{MATERIALS AND METHODS Plant Materials}

Thirty entries were evaluated during the 2002 and 2003 field seasons. Of these, 18 were $\mathrm{F}_{5}$ experimental "waxy" lines developed from a cross of PI436626 and Huntsman. These lines were the result of four rounds of selection for waxy starch character, plant height, panicle shape, and early maturity. The remaining lines in the trial were the parents, as described above, another waxy accession, PI436625, and nine nonwaxy, adapted lines as a control group for the evaluation of agronomic traits: 'Horizon', 'Sunup', 'Sunrise', 'Earlybird', 'Dawn', 9668-17, 9213, 9308, and 9217-L. A list of entries in this trial is shown in Table 1. 


\section{Plot Management and Data Collection}

Trials were planted 2002 and 2003 at seven locations in Nebraska, Colorado, and Wyoming. All Nebraska trials were planted in plots $1.2 \mathrm{~m}$ wide and $5.2 \mathrm{~m}$ long $\left(6.3 \mathrm{~m}^{2}\right)$ with four rows at $30-\mathrm{cm}$ spacing. At Wyoming and Colorado locations, plots were planted in plots $1.5 \mathrm{~m}$ wide and $4.5 \mathrm{~m}$ long $\left(6.8 \mathrm{~m}^{2}\right)$ in six rows at $25-\mathrm{cm}$ spacing. Regardless of planting technique or seed size, the target seeding rate was $16.8 \mathrm{~kg} \mathrm{ha}^{-1}$.

Heading notes were taken at weekly intervals at four environments in 2002. Heading date was defined as the date at which $50 \%$ of heads within a plot were fully emerged from the boot and panicle stem was visible above the flag leaf. This date was then converted to day of year (DOY), from which the DOY of planting was subtracted to give days from planting to heading.

Plant height was recorded at seven locations, five from the 2002 season and two from the 2003 season. Height was measured from the ground to the highest point of a plant determined by visual inspection to be of representative height in that plot. Bent panicles were not straightened out for this measurement.

Lodging was recorded only at the four locations when and where it occurred, in late August of the 2002 season. Lodging was determined by visual inspection and rated from 0 to 10 as severity increased.

All plots were directly harvested using a small plot combine. In Nebraska, harvested plot area was $4.5 \mathrm{~m}^{2}$ (70\% of plot); at the Wyoming and Colorado plots, harvested area was $3.6 \mathrm{~m}^{2}(48 \%$ of plot). Onboard electronic data collection included grain yield, grain moisture (\%), and test weight. In addition, a small subsample was taken from each sample and stored for further evaluation, including seed size measurements and starch characterization.

Planting and harvest dates, as well as soil information for the sites, are found in Table 2.

\section{Experimental Design and Statistical Analysis}

The experiment comprised 30 entries and was conducted in a randomized complete block design with four replicates at each of the seven environments. The trial consisted of three locations in 2002 and four locations in 2003.

Because the range of climatic patterns between locations in a given year can vary as much as between years at the same location, the year and location effects were analyzed together as the environmental effect. Environment and replication were analyzed as random effects, while genotype was analyzed as a fixed effect.

Analyses of days to heading, plant height, lodging, yield, grain volume weight, and seed size were conducted using SAS (SAS Institute, 2003). PROC MIXED was used for analysis of variance, and Fisher's LSD was used to compare individual line means.

Stability of agronomic traits was determined by regressing genotype mean response on an index of environmental mean response (Eberhart and Russell, 1966). Location means served as the $X$ coordinates for locations along the environmental index. The line within location means were then plotted on the $Y$-axis above their location mean. Regression lines were then fitted to these points and the coefficients tested for significant difference from $b=1.0$ by use of an $F$ test. Correlation of trait means with one another, and of means with their $b$-values, was done using the CoStat package (CoHort Software, 2001).

Yield is the predominant factor in selecting a line or lines for release. In this study, we examined the overall mean for a given line and its regression slope. Theoretically, a slope of 1 demonstrates stability; that is, as the environment improves, the response of a given line is relative to the body of entries tested in those environments. For yield, this is straightforward, and we could expect a cultivar with a regression slope of 1.3 to respond very well to a high yield environment. Conversely, a cultivar with a regression slope of 0.6 may yield relatively similarly across environments (and years) but may not utilize beneficial site and/or climate factors to increase yield.

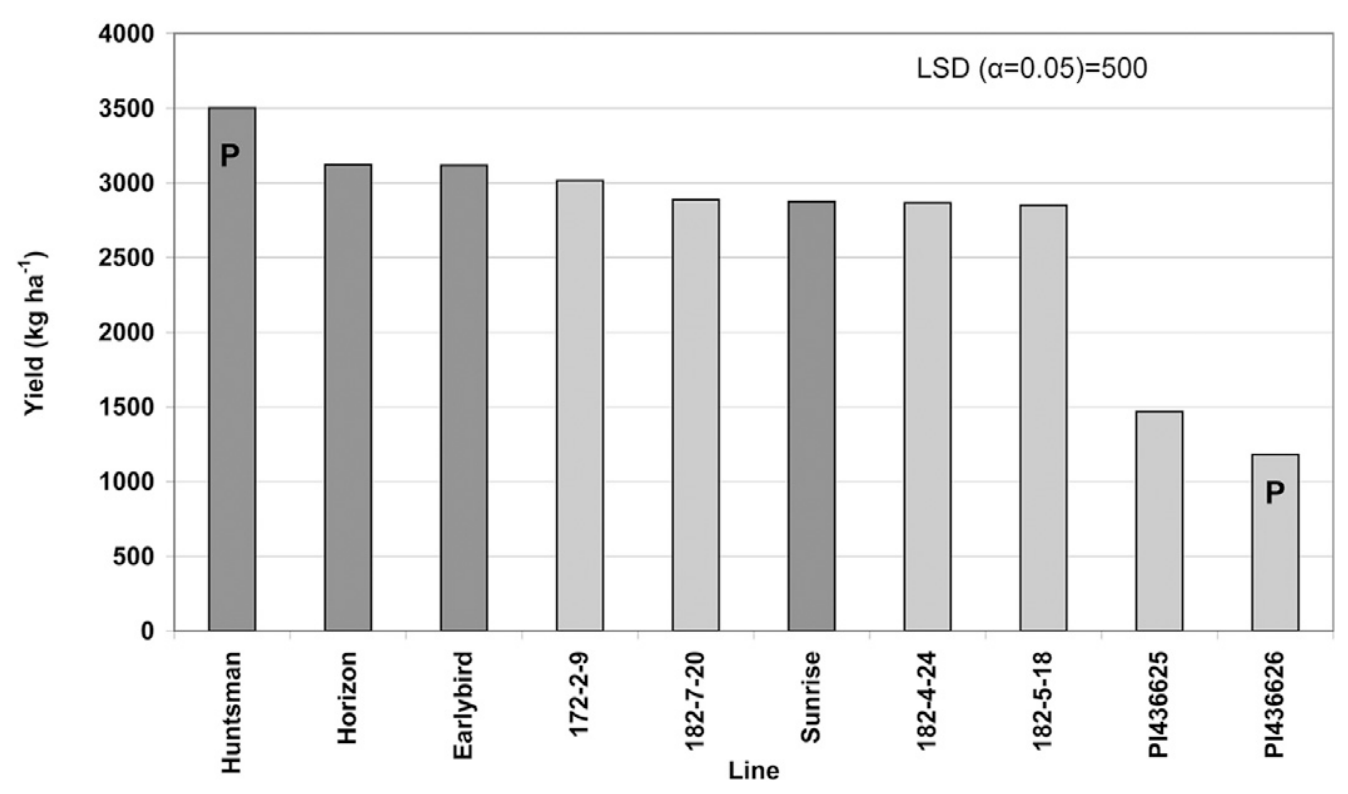

Figure 1. Overall mean yields (kg ha-1) for selected proso lines (10 of 30) from the 2002-2003 trial. Selected lines represent top eight lines and waxy Chinese plant introduction. Lighter gray bars denote waxy lines, capital $P$ denotes parents of experimental line. 
For the regression plots (Fig. 1; see results), the waxy lines with both the highest and lowest mean values for each variable measured are plotted along with the parents, the mean of the 10 checks, and the mean of all waxy lines simply to explore the range of response in the waxy lines. Any choice of a cultivar for release would be guided primarily by mean values across environments and only secondarily based on any evaluation of stability across environments.

\section{RESULTS AND DISCUSSION Yield}

Yield varied significantly across lines at all locations (Table 3). Waxy progeny lines all produced significantly more grain than PI436626 in all environments. However, waxy progeny mean yield was significantly less than the check lines. Mean waxy progeny yield was lower than Huntsman at all locations but was significantly less at only three environments.

Across the environmental index, PI436626 was the lowest-yielding entry. Part of this is because this line was extremely late to mature, and grain filling was not completed at harvest time. Some waxy progeny lines did not yield significantly less grain than checks or Huntsman at lower environmental means but showed less response to high yield environments than did either the checks or Huntsman. The top-yielding waxy progeny line, 172-2-9 (mean $=3016 \mathrm{~kg}$ $\mathrm{ha}^{-1}$ ), was not significantly different from Huntsman (mean $=3501 \mathrm{~kg} \mathrm{ha}^{-1}$ ) across locations and surpassed the mean of check cultivars $\left(2837 \mathrm{~kg} \mathrm{ha}^{-1}\right.$ ) across locations as well.

Regression analysis showed crossover of top-yielding waxy and the nonwaxy mean at low environmental means (Fig. 2d). Waxy progeny slopes ranged from 0.80 to 1.25 (line 172-2-9), while the slope was 1.11 for Huntsman and 0.74 for PI436626.

Yield is the predominant factor in selecting a line or lines for release. Examining the lines individually, the mean yield of 172-2-9 averaged across locations was not significantly less than the yield of Huntsman (Fig. 1). This line was shorter in stature, had smaller seeds, and had lower test weight than Huntsman but was not significantly different in lodging or days to heading.

Examining the lines at individual locations shows drastic and erratic rank change. For instance, while Huntsman is known to have high grain yield, and ranked first in this trial by overall mean, it ranked first in only two environments in the midrange of the environmental index. It ranked fifth, sixth, seventh, and ninth in the other environments. Horizon, a 2003 release, ranked second in mean yield across locations but ranked second in two environments, then 4th, 7th, and 9th, and 20th (twice) at the other locations. Earlybird ranked third overall, but actually ranked first at one location but came in at 6 th, 8th, 10th, 15th, and 18th at the others.

Likewise, the top-yielding experimental waxy line, 172-2-9, ranked fourth in mean yield across locations but ranked $3 \mathrm{rd}, 7 \mathrm{th}$, 9th and 14 th at the various locations. Another high-yielding waxy line, 182-7-20, ranked sixth overall, but came in 2 nd and 5 th at two locations and 12th, 13th, 18th, and 21st at the individual locations.

The complex changing of ranks makes it difficult to ascertain the nature of each line's response to environmental factors. However, stability parameters show that most of the top-yielding waxy lines are relatively stable (Table 4). Like Huntsman, Horizon, and Earlybird, experimental lines 172-2-9 and 182-4-24 have regression coefficients significantly steeper than 1.0. This suggests that they respond well to high-yielding environments. The slope of the regressions lines for 11 other lines do not differ significantly from unity and thus would be expected to be equally well suited to a range of environments.

Peterson et al. (1992) examined the correlation between quality parameters and their regression slope $(b$ value) across environments as a means of evaluating $G \times E$ interaction in wheat. In the present study, genotype means and $b$ values for yield were highly correlated $(r=0.56$, $p=0.0014)$, suggesting that higher-yielding lines were also more likely to rank evenly across environments, utilizing high-yield environments but potentially suffering in low-yield locales.

Table 3. Analysis of variance: degrees of freedom and mean squares (MS) for agronomic traits for 30 proso lines, 2002 and 2003. Discrepancies in degrees of freedom can be attributed to missing data values, and locations dropped from individual analyses.

\begin{tabular}{|c|c|c|c|c|c|c|c|c|c|c|c|c|}
\hline \multirow{2}{*}{ Source } & \multicolumn{2}{|c|}{ Grain yield } & \multicolumn{2}{|c|}{ Testweight } & \multicolumn{2}{|c|}{ Seed size } & \multicolumn{2}{|c|}{ Plant height } & \multicolumn{2}{|c|}{ Lodging } & \multicolumn{2}{|c|}{ Days to heading } \\
\hline & df & MS & df & MS & df & MS & df & MS & df & MS & df & MS \\
\hline Genotype (G) & 29 & $5771523^{* \star *}$ & 29 & $10614^{\star \star \star}$ & 29 & $4.902^{\star \star \star}$ & 29 & $48466^{\star \star \star}$ & 29 & $8.38 \mathrm{NS}^{\dagger}$ & 29 & $1092.2^{* \star *}$ \\
\hline Environment (E) & 6 & $90751620^{\star \star *}$ & 5 & $143868^{\star \star \star}$ & 6 & $9.683^{\star \star \star}$ & 6 & $247056^{\star \star \star}$ & 3 & $314.68^{\star \star \star}$ & 3 & $1461.1^{\star \star \star}$ \\
\hline $\mathrm{G} \times \mathrm{E}$ & 170 & $906564^{\star \star \star}$ & 134 & $4425^{\star \star \star}$ & 174 & $0.210^{\star \star \star}$ & 141 & $16204^{\star \star \star}$ & 87 & $7.55^{\star \star}$ & 87 & $29.8^{\star \star \star}$ \\
\hline Rep(Env) & 18 & $767175^{\star}$ & 13 & 2183 NS & 17 & $0.430^{* * *}$ & 15 & $679557^{* * \star}$ & 9 & $10.45^{\star}$ & 9 & $20.6^{*}$ \\
\hline Residual & 592 & 402128 & 481 & 2381 & 563 & 0.114 & 510 & 29216 & 348 & 4.64 & 348 & 8.6 \\
\hline Total & 818 & & 665 & & 792 & & 583 & & 479 & & 479 & \\
\hline
\end{tabular}

*Significant at the 0.05 probability level.

${ }^{* *}$ Significant at the 0.01 probability level.

${ }^{* * \star}$ Significant at the 0.001 probability level.

${ }^{\dagger} \mathrm{NS}$, not significant. 

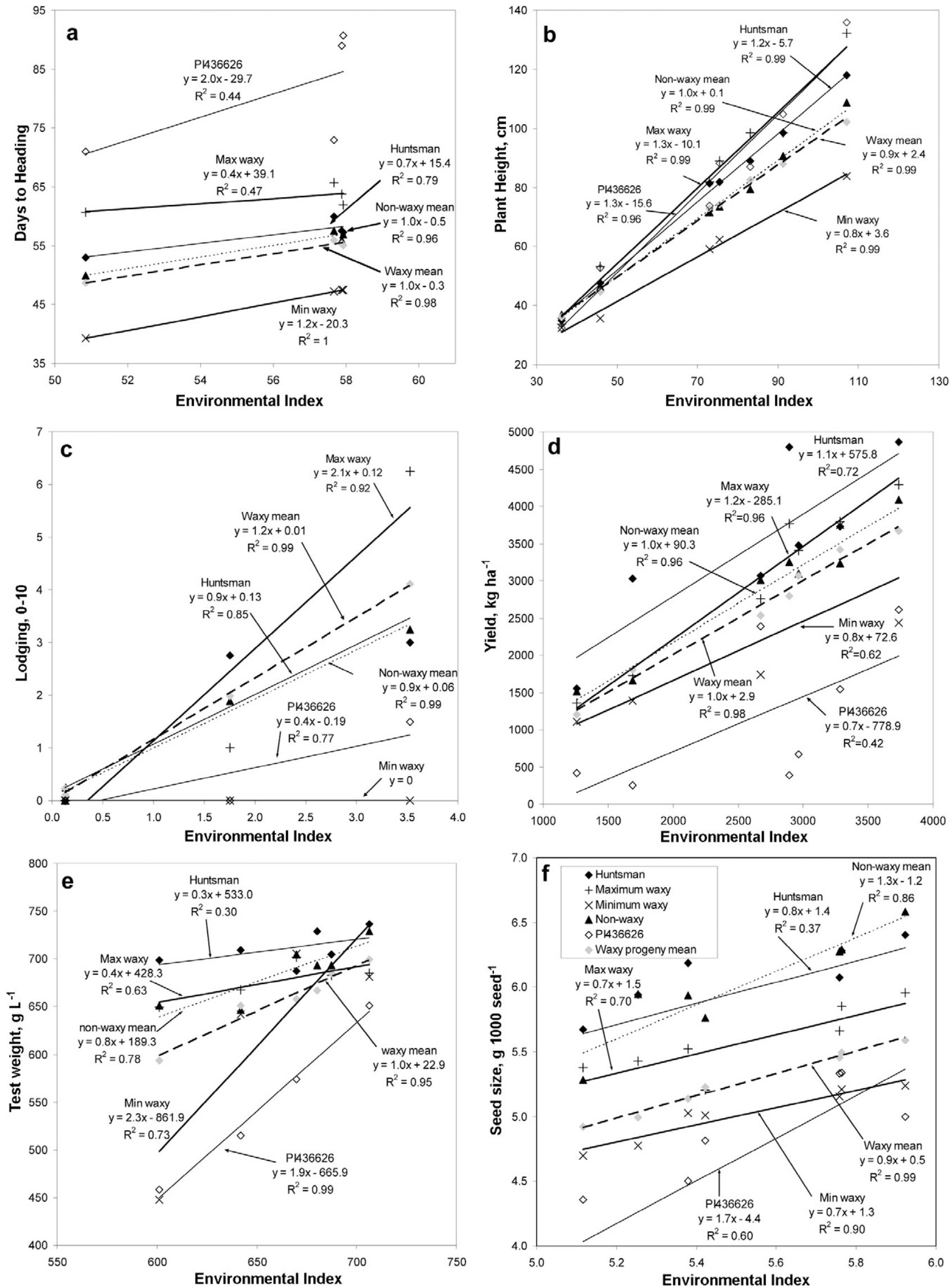

Figure 2. Environmental variation for (a) days to heading, (b) plant height (cm), (c) lodging (0-10), (d) yield (kg ha-1), (e) test weight $\left(\mathrm{g} \mathrm{L}^{-1}\right)$, and $(f)$ seed size $\left(\right.$ seed $\mathrm{g}^{-1}$ ). Heavy lines show maximum and minimum individual waxy progeny lines for each trait; dashed line shows waxy progeny mean. Location means served as the $X$ coordinates for locations along the environmental index. The line within location means were then plotted on the $Y$-axis above their location mean. 
Table 4. Means and stability parameters of 30 proso lines for six agronomic traits evaluated at seven locations in the central Great Plains, 2002 and 2003.

\begin{tabular}{|c|c|c|c|c|c|c|c|c|c|c|c|c|}
\hline \multirow{3}{*}{ Lines } & \multicolumn{3}{|c|}{ Grain yield } & \multicolumn{3}{|c|}{ Test weight } & \multicolumn{3}{|c|}{ Seed size } & \multirow{3}{*}{$\begin{array}{c}\text { Days to } \\
\text { heading } \\
\text { Mean }\end{array}$} & \multirow{3}{*}{$\begin{array}{l}\text { Plant } \\
\text { height } \\
\text { Mean }\end{array}$} & \multirow{3}{*}{$\begin{array}{c}\text { Lodging } \\
\text { Mean }\end{array}$} \\
\hline & \multirow[b]{2}{*}{ Mean } & \multicolumn{2}{|c|}{$\begin{array}{c}\text { Stability } \\
\text { parameters }\end{array}$} & \multirow[b]{2}{*}{ Mean } & \multicolumn{2}{|c|}{$\begin{array}{c}\text { Stability } \\
\text { parameters }\end{array}$} & \multirow[b]{2}{*}{ Mean } & \multicolumn{2}{|c|}{$\begin{array}{c}\text { Stability } \\
\text { parameters }\end{array}$} & & & \\
\hline & & $b$ & $R^{2}$ & & $b$ & $R^{2}$ & & $b$ & $R^{2}$ & & & \\
\hline & $\mathrm{kg} \mathrm{ha}^{-1}$ & & & $\mathrm{~g} \mathrm{~L}^{-1}$ & & & $\begin{array}{l}\text { g } 1000 \\
\text { seed }^{-1}\end{array}$ & & & $d$ & $\mathrm{~cm}$ & $0-10$ \\
\hline Huntsman & $3501^{\dagger}$ & 1.107 & 0.7218 & $711^{\dagger}$ & 0.268 & 0.2945 & $5.97^{\dagger}$ & 0.823 & 0.3722 & $57^{\dagger}$ & $79^{\dagger}$ & $1.4^{\dagger}$ \\
\hline Horizon & $3121^{\dagger}$ & 1.037 & 0.8292 & $698^{\dagger}$ & 0.723 & 0.8652 & $6.17^{\dagger}$ & 0.771 & 0.7755 & $55^{\dagger}$ & 68 & $0.9^{\dagger}$ \\
\hline Earlybird & $3117^{\dagger}$ & 1.160 & 0.8167 & $688^{\dagger}$ & 0.553 & 0.5895 & $6.21^{\dagger}$ & 1.050 & 0.5808 & $56^{+}$ & 74 & $0.5^{\dagger}$ \\
\hline $172-2-9$ & $3016^{\dagger}$ & 1.249 & 0.9590 & 663 & 0.246 & 0.3596 & 5.34 & 0.871 & 0.9932 & $54^{\dagger}$ & 67 & $0.9^{\dagger}$ \\
\hline $9668-17$ & 2979 & 1.176 & 0.8770 & $699^{\dagger}$ & 0.529 & 0.4576 & $6.13^{\dagger}$ & 1.133 & 0.7466 & 51 & 70 & $1.2^{\dagger}$ \\
\hline 9308 & 2919 & 1.029 & 0.8890 & $689^{\dagger}$ & 1.182 & 0.9608 & 6.31 & 0.856 & 0.5326 & $54^{\dagger}$ & 74 & $1.2^{\dagger}$ \\
\hline $182-7-20$ & 2887 & 1.053 & 0.8033 & 648 & -0.004 & 0.0000 & 5.55 & 1.077 & 0.9383 & $59^{\dagger}$ & $76^{+}$ & $0.4^{\dagger}$ \\
\hline Sunrise & 2875 & 0.864 & 0.7213 & $701^{\dagger}$ & 0.380 & 0.7592 & $6.00^{\dagger}$ & 1.647 & 0.7365 & $56^{\dagger}$ & $75^{\dagger}$ & $1.6^{\dagger}$ \\
\hline $182-4-24$ & 2866 & 1.180 & 0.7833 & 663 & -0.116 & 0.0128 & 5.51 & 1.302 & 0.8629 & 63 & 84 & $0.0^{\dagger}$ \\
\hline $182-5-18$ & 2850 & 0.610 & 0.4819 & 660 & 2.218 & 0.6686 & 5.52 & 0.898 & 0.8567 & 53 & $75^{\dagger}$ & $1.6^{\dagger}$ \\
\hline $172-2-B$ & 2834 & 0.794 & 0.7742 & 656 & 1.053 & 0.8008 & 5.01 & 0.653 & 0.9016 & 50 & 64 & $1.0^{\dagger}$ \\
\hline $177-9-13$ & 2814 & 1.109 & 0.8314 & 648 & 1.031 & 0.8012 & 5.34 & 0.665 & 0.7937 & $60^{+}$ & $79^{\dagger}$ & $3.0^{\dagger}$ \\
\hline 9213 & 2801 & 0.977 & 0.7413 & 661 & 0.862 & 0.8654 & $5.99^{\dagger}$ & 1.074 & 0.9406 & 62 & $76^{\dagger}$ & $2.4^{\dagger}$ \\
\hline $174-7-13$ & 2793 & 1.001 & 0.8698 & 655 & 2.026 & 0.7560 & 5.14 & 0.994 & 0.8886 & $60^{+}$ & $75^{\dagger}$ & $2.0^{\dagger}$ \\
\hline 9217-L & 2734 & 0.985 & 0.8230 & $690^{\dagger}$ & 0.713 & 0.8275 & $5.96^{\dagger}$ & 1.552 & 0.5336 & $55^{\dagger}$ & 71 & $2.4^{\dagger}$ \\
\hline $177-3-13$ & 2710 & 1.169 & 0.9069 & 672 & 0.457 & 0.4265 & 5.52 & 0.881 & 0.8316 & $59^{\dagger}$ & $80^{\dagger}$ & $1.8^{\dagger}$ \\
\hline $177-9-12$ & 2698 & 0.967 & 0.9162 & 658 & 1.021 & 0.7783 & 5.57 & 0.743 & 0.6982 & $57^{\dagger}$ & $80^{\dagger}$ & $2.3^{\dagger}$ \\
\hline $177-8$ & 2635 & 1.020 & 0.9138 & 658 & 0.683 & 0.5185 & 5.34 & 0.518 & 0.8070 & 52 & 73 & $1.4^{\dagger}$ \\
\hline Sunup & 2628 & 1.110 & 0.7073 & $682^{\dagger}$ & 0.900 & 0.3439 & $5.83^{\dagger}$ & 0.918 & 0.6882 & $56^{\dagger}$ & $75^{\dagger}$ & $0.9^{\dagger}$ \\
\hline $177-9-2$ & 2628 & 0.999 & 0.7802 & 654 & 0.407 & 0.5755 & 5.40 & 0.813 & 0.6463 & $58^{+}$ & $78^{\dagger}$ & $2.1^{\dagger}$ \\
\hline $177-7-5$ & 2622 & 1.184 & 0.9231 & 660 & 0.405 & 0.2289 & 5.16 & 0.610 & 0.4454 & 62 & $78^{\dagger}$ & $2.0^{\dagger}$ \\
\hline 10097 & 2498 & 1.189 & 0.9452 & $676^{+}$ & 0.864 & 0.7956 & 5.01 & 0.665 & 0.9084 & 50 & 66 & $1.8^{\dagger}$ \\
\hline 10110 & 2466 & 0.952 & 0.8652 & $677^{\dagger}$ & 0.377 & 0.6276 & 5.10 & 0.704 & 0.7997 & 48 & 63 & $1.3^{\dagger}$ \\
\hline Dawn & 2349 & 1.012 & 0.7810 & 669 & 0.916 & 0.5335 & $5.98^{\dagger}$ & 0.925 & 0.7769 & 50 & 69 & $1.2^{\dagger}$ \\
\hline 10135 & 2325 & 0.985 & 0.9691 & 650 & 1.658 & 0.8476 & 5.12 & 1.065 & 0.7305 & 47 & 63 & $1.3^{\dagger}$ \\
\hline $175-5$ & 2298 & 0.859 & 0.7078 & 648 & 1.727 & 0.7029 & 5.10 & 0.947 & 0.7117 & 47 & 63 & $1.1^{\dagger}$ \\
\hline 10107 & 2107 & 0.845 & 0.7456 & 649 & 1.643 & 0.9173 & 5.05 & 1.000 & 0.8761 & 46 & 56 & $2.1^{\dagger}$ \\
\hline 10127 & 2082 & 0.795 & 0.6164 & 619 & 2.262 & 0.7339 & 5.13 & 0.924 & 0.6471 & 45 & 55 & $1.4^{\dagger}$ \\
\hline PI436625 & 1468 & 0.715 & 0.5486 & 555 & 2.534 & 0.9584 & 5.34 & 2.269 & 0.7359 & 80 & 89 & $0.0^{+}$ \\
\hline PI436626 & 1180 & 0.741 & 0.4235 & 549 & 1.856 & 0.9891 & 4.69 & 1.655 & 0.6008 & 81 & $82^{\dagger}$ & $0.4^{\dagger}$ \\
\hline LSD & 500 & & & 38 & & & 0.24 & & & 4 & 4.5 & 1.9 \\
\hline Mean & 2627 & & & 664 & & & 5.52 & & & 56 & 73 & 1.4 \\
\hline
\end{tabular}

†Indicates mean that is not significantly different from Huntsman's mean.

\section{Test Weight}

Test weight measurement required a given amount of seed for the harvester's instrument to function. Because more than half of the plots had very low volume, one of seven locations was dropped from 2002 data, and only six locations are included in this analysis.

This variable responded quite erratically to environmental effects. Multiple crossovers occurred in the midrange of the environmental index. PI436626 had the lowest test weight across all environments. On the other hand, Huntsman was the highest at all but one location. The waxy progeny with the highest mean test weight across locations had the lowest response at the high end of the environmental index, but the highest response at the low end. The reverse was true of the lowest waxy progeny line, and the two completely reversed ranks across locations. The high waxy line had a meager slope 0.38 , relatively parallel to Huntsman at 0.27 (Fig. 2e). The low waxy line had a slope of greater than 2.0.

At lower environmental means, the spread between lines was greater than at higher environmental means. Waxy progeny line means ranged from 619 to $677 \mathrm{~g} \mathrm{~L}^{-1}$. Huntsman was higher at $710 \mathrm{~g} \mathrm{~L}^{-1}$, while PI436626 was significantly lower at $550 \mathrm{~g} \mathrm{~L}^{-1}$. For this trait, it is preferred to have a high mean and a low slope (approaching zero).

Genotype means and $b$ values for test weight were highly negatively correlated $(r=-0.62, p=0.0002)$, sug- 
gesting that lines with a higher test weight are more stable across environments while lines with a lower mean test weight are less stable.

Line means for test weight were also strongly correlated with line means for yield $(r=0.87, p<0.0001)$, suggesting that high-yielding lines were also likely to have acceptable test weight.

\section{Seed Size}

Seed size exhibited somewhat erratic response across the seven environments. Crossover of regression lines occurred in the midrange of the index between Huntsman and the nonwaxy check mean. However, nonwaxy checks (some very large seeded lines, such as Horizon, Earlybird, and 9308) had the largest seeds at all but two environments, where they were superseded by Huntsman. Across environments, PI436626 had the smallest seeds at all but two locations. Crossover of regression line for PI436626 and the smallest-seeded waxy line occurred near the upper end of the index. Slopes for Huntsman, the high mean waxy line (177-9-12), and the mean of waxy lines exhibited a high level of parallelism $(b=0.82,0.74$, and 0.86 , respectively) (Fig. 2f).

Line means for waxy progeny ranged from 5.006 to

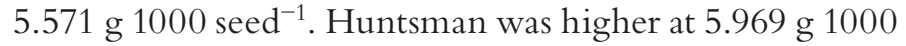
seed $^{-1}$, and PI436626 was much lower at $4.695 \mathrm{~g} 1000$ seed $^{-1}$. Genotype means and $b$ values were poorly correlated $(r=0.07, p=0.70)$. In addition, the range of values across lines (4.36-6.31 g $1000 \mathrm{seed}^{-1}$ ) was broader than

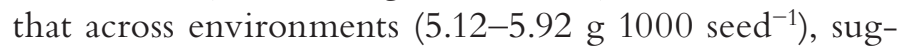
gesting that seed size is more influenced by genotype than environment, and selection for heavier (or larger) seeds was independent of selection for yield.

\section{Days to Heading}

Days to heading was measured at four trial locations, all from the 2002 season. Plotting the response of six series (waxy progeny mean, high and low waxy lines, check line mean, PI436626, and Huntsman) across an environmental index showed no crossover in the response of the series (Fig. 1a). The waxy parent (PI436626) exhibited a slope approaching 2.0 (data not shown), suggesting that when environmental factors slow maturity, these lines become very late. All other classes had slopes less than or very close to unity. Experimental waxy lines individually showed regression slopes ranging from 0.42 to 1.40 , generally showing more stability for this characteristic than the waxy parent did. Mean days to heading for the waxy lines ranged from 45 to $63 \mathrm{~d}$, all of which were by far earlier than PI436626.

An initial examination of the correlation of days to heading and yield showed a significant negative correlation $(r=-0.38, p=0.0368)$; that is, later maturity produced lower yields. This result is similar to those noted by Baumhardt and Howell (2006) in sorghum. The late maturity and low yields of the PI waxy parental lines made them extreme outliers, and when removed, days to heading and yield are strongly positively correlated $(r=0.58, p$ $=0.0012)$. The mean days to heading of leading waxy test line was $54 \mathrm{~d}$, quite similar to Huntsman at $57 \mathrm{~d}$. Across all lines, high-yield lines tended to cluster between 50 and $60 \mathrm{~d}$, with both very late and very early lines having lower yield. In the region of this study, late maturity runs the risk of crop loss due to killing frost or loss to hail before grain fill is complete.

\section{Plant Height}

Heights exhibited crossover at lower environmental means. PI436626 tended to be the shortest line at the low end of the index but tended to be tallest at the high end (Fig. 2b). At low environmental means, waxy progeny were taller than check lines but shorter than Huntsman; at higher means, waxy progeny were shorter than both parents and nonwaxy checks. Waxy progeny line 182-4-24 was the tallest across all environments.

Regression slopes for waxy progeny varied from 0.76 to 1.28 (data not shown). Huntsman had a slope of 1.15 , while PI436626 had a slope of 1.34. Mean plant height for waxy progeny lines ranged from 55 to $84 \mathrm{~cm}$; Huntsman mean height was $79 \mathrm{~cm}$, and PI436626 was $82 \mathrm{~cm}$.

\section{Lodging}

Lodging was noted at only four locations, and locations free from lodging were not included in the analysis. Lodging varied significantly across varieties at two individual locations. Across the environmental index, PI436626 was less prone to lodging than the waxy progeny mean, despite being among the tallest. However, this line was still fairly green and immature when lodging notes were taken, and lack of a heavy seed head could have skewed these values. Across locations, one waxy progeny line was most prone to lodging: 177-9-13. In contrast, one waxy progeny line, 182-4-24, did not lodge at any location despite great height and above-average yield.

Regression slopes for individual waxy progeny lines ranged from 0 to 1.75; Huntsman had a slope of 0.94 and PI436626 had a slope of merely 0.41 (Fig. 2c). Waxy progeny means ranged from 0 to 3.0 (on a 1-10 scale); Huntsman had a mean of 1.44, and PI436626 had a mean of 0.38 .

\section{CONCLUSIONS}

Despite the waxy progeny's great variation in all traits examined, it is clear that some lines within the group can express most traits (in addition to waxy starch character) in the range of the adapted parent Huntsman, and well within range of the older check cultivars. Among these lines, several combine expression of multiple traits in favorable ranges. Especially promising is 172-2-9, which 
features high yield potential, appropriate maturity, and relative stability across environments, a demonstrated response to higher-yield environments, and perhaps irrigated cropping if the value of the crop can justify the added inputs.

In addition, our key variables in this study-yield, test weight, and seed size-seemed to be under more influence from genotype than environmental factors, suggesting that successful selection of leading lines may require fewer test locations and/or years. Perhaps proso's documented low water requirements (Baltensperger, 2002) could allow these selections a reasonable likelihood of successful proso cropping in any given year in the study's geographical range.

It is clear that the waxy trait can be integrated into the genetic background of the region without sacrificing yield potential and appropriate maturity levels.

\section{References}

Baltensperger, D.D. 1996. Foxtail and proso millet. p. 182-190. In J. Janick (ed.) Progress in new crops. ASHS Press, Alexandria, VA.

Baltensperger, D.D. 2002. Progress with proso, pearl and other millets. p. 100-103. In J. Janick and A. Whipkey (ed.) Trends in new crops. ASHS Press, Alexandria, VA.

Baumhardt, R.L., and T.A. Howell. 2006. Seeding practices, cultivar maturity, and irrigation effects on simulated grain sorghum yield. Agron. J. 98:462-470.

Bergener, P.A. 2002. Proso millet prices 2002: Another volatile year. p. 5. In Nebraska proso, sunflower, pulse crop, ama- ranth, oat, and barley variety tests 2002. Extension Circular EC02-107-A. Univ. of Nebraska, Lincoln.

CoHort Software. 2001. CoStat user's guide, version 6.002. Monterrey, CA.

Demeke, T., P. Hucl, R.B. Nair, T. Nakamura, and R.N. Chibbar. 1997. Evaluation of Canadian and other wheats for waxy proteins. Cereal Chem. 74:442-444.

Eberhart, S.A., and W.A. Russell. 1966. Stability parameters for comparing varieties. Crop Sci. 6:36-40.

FAO. 2008. FAOStat. Available at http://faostat.fao.org/site/567/ DesktopDefault.aspx?PageID=567 (verified 16 Jan. 2008). FAO, Rome.

Graybosch, R.A., and D.D. Baltensperger. 2008. Evaluation of the waxy endosperm trait in proso millet (Panicum miliaceum L.). Plant Breed. (in press).

Heyduck, R.F., D.D. Baltensperger, R. Graybosch, L. Nelson, and G. Frickel. 2002. Agronomic evaluation of waxy proso millets in the high plains. In 2002 Agronomy Abstracts. ASA, Madison, WI.

Jane, J., Y.Y. Chen, L.F. Lee, A.E. McPherson, K.S. Wong, M. Radosavljevic, and T. Kasemsuwan. 1999. Effects of amylopectin branch chain length and amylose content on the gelatinization and pasting properties of starch. Cereal Chem. 76:629-637.

Lineback, D.R. 1999. The chemistry of complex carbohydrates. p. 115-119. In S.S. Cho, L. Prosky, and M. Dreher (ed.) Complex carbohydrates in foods. Marcel Dekker, New York.

Peterson, C.J., R.A. Graybosch, P.S. Baenziger, and A.W. Grombacher. 1992. Genotype and environment effects on quality characteristics of hard red winter wheat. Crop Sci. 32:98-103.

SAS Institute. 2003. SAS procedures guide, version 6.12. SAS Inst., Cary, NC. 